\title{
Assessment of Knowledge and Attitudes of Students regarding to Food Allergy at Assiut University
}

\author{
Shaimaa GH. Ali, Soad A. Sharkawy \& Fayza M. Mohammed \\ Clinical Demonstrator in Community Health Nursing Faculty of Nursing- Assiut University, Egypt. \\ Assistant Professor of Community Health Nursing Faculty of Nursing- Assiut University, Egypt. \\ Lecturer of Community Health Nursing Faculty of Nursing- Assiut University, Egypt.
}

\begin{abstract}
Background: Food Allergy is an abnormal response to a food protein triggered by the body's immune system. Aim of the study: to assess knowledge and attitudes of students about food allergy at Assiut University. Research design: descriptive research design was used in this study. Setting: The study was conducted in 4 randomly selected faculties at Assiut University (Faculty of Social Work, Computers and Information, Arts and Veterinary Medicine). Total sample was 931 students. Two tools was used (first tool) A structured self-administered questionnaire. (second tool) likert scale to assess attitude toward food allergy. Results: Finding revealed that more than two fifth of them were 20-21 years old. About three quarter of studied students had poor score of knowledge, while only $4.9 \%$ of them had good score of knowledge. The majority of studied students had positive attitudes toward food allergy. Conclusion: The study concluded that there were lack of knowledge about food allergy. There was a statistical significant difference between sex, mother's education and their knowledge. Recommendations: The study recommended that develop plan, and implement health education programs for university students about food allergy.
\end{abstract}

Keywords: Assiut University, Students, Knowledge, Attitudes \& Food Allergy.

\section{Introduction}

Eating is necessary for life. Eating is an enjoyable experience given the variety and abundance of foods available in the market place for most consumers. However, consuming certain foods can be a debilitating, possibly even life-threatening, experience for some individuals who have food allergies and sensitivities must avoid certain foods or food ingredients in their diets so, the joy of eating is diminished (Boye, 2012).

Food selection can become a tedious task requiring the painstaking reading of ingredient lists on the labels of packaged foods and a ceaseless search for more knowledge about food composition. Food preparation requires careful attention to details such as "cooking from scratch," seeking alternative recipes for many dishes, and avoidance of shared utensils, containers, and cooking surfaces between allergenic and non-allergenic foods (Burks et al., 2012).

A food allergy is a reaction of the immune system in response to proteins in food. Ingesting the offending food causes the release of massive amounts of chemicals, including histamines, resulting in symptoms of an allergic reaction. Food allergy is a serious public and personal health concern that affects approximately 10-12 million individuals (Food Allergy \& Anaphylaxis Network (FAAN), 2011).

Population surveys in the United States and Canada, which are mainly performed in children, have concluded that the self-reported adverse reactions after the ingestion of foods are estimated to be between 12-20\%. Current data suggest that food allergy affects more than $1 \%$ to $2 \%$ but less than $10 \%$ of the general population and it still remains unclear whether the prevalence is increasing (Sicherer, 2011 \& Chafen et al., 2010).

The study carried out by ( Hossny et al., 2011) in Cairo on 100 children diagnosed to have allergy diseases and found that (17\%) of children had food allergy. Symptoms of an allergic reaction may include rashes, swelling, hives, itching, loss of consciousness, trouble breathing, and wheezing. Anaphylaxis is a severe form of allergic reaction that can cause hypotension, loss of consciousness, and possibly death (FAAN, 2011).

In addition to big eight food allergens such as eggs, milk, soy, fish, shellfish, tree nut, peanut and wheat, other food allergens such as fruits, chocolate, red dye, tomatoes, orange juice, spices, and cheese are also common among children (Ministry of Health (MOH), 2013).

About $50 \%$ of children with allergies to milk, egg, soy, and wheat will outgrow their allergy by the age of 3-6 years. Those who are still allergic by the age of 12. Some food such as nuts, legumes, fish, and shellfish tend to have allergies throughout their life times Risk factors of Food allergy include; Family history, a past food allergy, age, asthma and Other allergies such as hay fever or eczema (Harold et al., 2007). 
Food allergy has significant deleterious effects on family economics, social interactions, school and work attendance, and health-related quality of life, Children with multiple food allergy face many nutritional problems as a consequence of an unsupervised elimination diet; failure to thrive and protein-losing enteropathy are the most severe chronic problems. The condition leads to extra stress for their families in terms of care at school, risk of death, and the need for emergency medication. In adults, allergic disorders lead to impaired quality of life, increased absenteeism from work, and reduced productivity when they are at work, and lead to a huge financial burden (National Institute of Allergy \& Infectious Disease (NIAID), 2010).

The nurse helps in preventing future exposure of the patient to the food allergen. In a severe allergic or anaphylactic reaction to food allergens has occurred, the nurse give instructions to the patient and family about strategies how to prevent it. The patient is instructed about careful reading of food labels and monitoring the preparation of food by others to avoid exposure to even minute amounts of allergenic foods and to avoid cross-contact (Greenhawt et al., 2009). Nurse should give patient and his family health education about early signs and symptoms of allergic reactions and emergency administration of epinephrine if a reaction occurs. Patients food allergies should be noted on their medical records, because there may be allergic reactions not only to food but also to some medications containing similar substances. Instruct Pregnant woman and those who are breast feeding to avoid eating peanuts to minimize the risk of peanut allergy in their children (Smeltzer et al., 2008).

\section{Significance of the Study}

The estimation for world population about 220-250 million people who have suffered from the allergic diseases. Although the incidence of Food allergy is hard to document, it has been estimated that food allergy (FA) affects $6-8 \%$ of children younger than 4 years of age and $2-4 \%$ of adults have allergies throughout their life- times (Pawankar et al., 2011 )

Cases involving food allergy and their effects seem to be growing all around the world. The effects of food allergy can range from mild to severe and even lead to death. It is also noted that students are among the frequent victims of food allergy. The cure for food allergy is unknown. Thus, a form of intervention is needed to prevent food allergy from occurring. In order to do so, an adequate level of knowledge concerning food allergy is crucial (Norrina, 2015).

\section{Aim of the study}

Assessment of knowledge and attitudes of students about food allergy at Assiut University.

Research question

- Are the students have a good level of knowledge regarding food allergy?

- Are the students have a positive attitudes regarding food allergy?

- Are there correlation between students' knowledge and their attitudes?

\section{Subjects \& methods \\ Research design}

Descriptive cross sectional research design was used in this study.

\section{Setting}

The study was conducted in 4 randomly selected faculties in Assiut University which named (Faculty of Social Work, Computers and Information, Arts and Veterinary Medicine) during academic year 2015-2016.

\section{Sample}

The Target population of this study involved male and female undergraduate "university students" in the previous faculties. Assiut University includes (16) faculties in Assiut city. It was categorized into two main groups of faculties. Group (1)"Health science faculties" included 5 faculties. Group (2)" Non Health science faculties". It included 11 faculties. The following faculties were excluded from the study (Faculty of Medicine, Nursing, Pharmacy, Education, Specific Education, Agriculture and Physical Education) because the last previous faculties their course include nutrition in their curriculum and then select randomly (4) faculties from the rest of faculties. Students were selected from each faculty by using convenient sample. Proportional sample was taken according to students' number and their sex in each faculty. Studied students was taken from all grades $1^{\text {st }}, 2^{\text {nd }}, 3^{\text {rd }}$ and $4^{\text {th }}$.

\section{Sample size}

The total number of students during academic year 2015-2016 in previous selected faculties are 18615 students . The estimated sample size found to be 931 students. Actually, it has been represented 5\% from each faculty and distributed as following:

\begin{tabular}{|l|c|c|}
\hline \multicolumn{1}{|c|}{ Faculty } & $\begin{array}{c}\text { Number of } \\
\text { students }\end{array}$ & $\begin{array}{c}\text { Sample size } \\
\text { (5\% from total } \\
\text { number of each } \\
\text { faculty) }\end{array}$ \\
\hline Faculty of Social Work & 4929 & 247 \\
\hline $\begin{array}{l}\text { Faculty of Computers } \\
\text { and Information }\end{array}$ & 1258 & 63 \\
\hline Faculty of Arts & 11077 & 554 \\
\hline $\begin{array}{l}\text { Faculty of Veterinary } \\
\text { Medicine }\end{array}$ & 1351 & 67 \\
\hline Total & 18615 & 931 \\
\hline
\end{tabular}




\section{Tools of data collection}

Two tools were used to collect data for this study after reviewing the relevant literature:

Tool (I): Self - administered questionnaire was developed by the researcher based on relevant literature to determine the level of students' knowledge and attitude toward food allergy at Assiut university, it included three parts:

Part (1): personal characteristics of the students such as age, sex, faculty name, class, residence, levels of education and occupation of their parents, kinship between father and mother.

Part (2): it included family history of food allergy disease. It was included 6 questions. It was distributed as following :( presence of allergic reaction to any particular type of food, the number of occurrences, the family suffers from a food allergy).

Part (3): Students' knowledge regarding food allergy. It was included 25 questions. It was distributed as:(definition of food allergy, risk factors, foods that cause food allergy, signs and symptoms, ingredients that cause food allergy, treatment for food allergy, prevention,...etc).

\section{Scoring system for knowledge}

Total score for knowledge items was (52) grade, a correct response was scored 1 grade and incorrect zero. The score of each item summed-up and then converted into percent score. (poor $=$ score $<50 \%$, satisfactory $=$ score $50-70 \%$, and good=score $>70 \%$ )

(Abd- El Rahman, 2014).

\section{Tool (II):-}

likert scale developed by ( Dillman, et al., 2007) To assess students' attitude regarding food allergy, It includes 14 statements, each statement have response as Strongly Disagree(1), Disagree(2), Neutral(3), Agree(4) and Strongly Agree(5).

\section{Scoring system for attitude:}

The total score was calculated by summing -up and then converting into a percent score. Students' attitude was considered positive if the score was $\geq 70 \%$ and negative attitude if the score was $<70 \%$ ).

\section{Statistical analysis}

The obtained data was reviewed, prepared for complete entry coded, analyzed and tabulated by using SPSS version 19 (Statistical Package for Social Science). Data were presented as number, percentage, mean, standard deviation. Chi-square test was used to compare between qualitative variables. Pearson correlation was done to measure correlation between quantitative variables. Statistical significance was considered at $\mathrm{p}$-value were less than $0.005(\mathrm{P}<0.05)$. Methods

\section{Administrative design}

Before conducting the study, an official approval letter was obtained from the dean of the faculty of nursing, Assiut University, to vice of university president for students' affairs of Assiut University. The letter included a permission to carry out the study and explained the purpose and the nature of the study.

\section{Data collection and field of the work}

Data was collected by the researcher, in the period from the mid of February to the end of April, 2016. Researcher took two days each week, 40-50 questionnaire sheet per day. The researcher introduced herself to the vice- deans for students' affairs at each selected faculties, and reminded them of the nature and purpose of the study. Then, she asked the vice-deans for students' affairs to take a copy of the study schedules of the selected grades of faculties.

The researcher was taken oral permission from the teaching staff members who were responsible for the desired lectures or sections, depending on their persuasion and the nature of each faculty, and then the researcher asked them about preferred time for data collection, either in the first or last part of the selected sections or lectures.

Researcher introduced herself to the students and explained the purpose and nature of the study and explained the main parts of the questionnaire were distributed to them. After that, the questionnaire was distributed to the students by the researcher. Students were asked to complete the questionnaire and were asked about any difficulty that might face them during answering the questionnaire.

Filling of questionnaire took 15-20 minutes by the students. After the students completed the questionnaire, the researcher collected the questionnaires with paying careful attention to incomplete answers to ask students to complete them. Finally, the researcher thanked the students and their teaching staff for their cooperation.

\section{Pilot study}

A pilot study was carried out before starting data collection on 93 students by $10 \%$, which were excluded from the study. The aim of pilot study was to test clarity of the tool and to estimate the time required to fill the questionnaire. Based on the results of pilot study modifications in the tools were done.

\section{Ethical considerations}

The researcher explained the purpose and nature of the study for each student. The student has the right to agree or disagree on participation in the study; consent to participate in the study was secured orally from every student and informed that the information obtained will be confidential and will use only for the purpose of the study 


\section{Results}

Table (1): Distribution of the studied students regarding to their socio-demographic characteristics at Assiut University, $(\mathrm{N}=931)$.

\begin{tabular}{|c|c|c|}
\hline socio-demographic characteristics & No. $(n=931)$ & $\%$ \\
\hline \multicolumn{3}{|l|}{ Age } \\
\hline$<20$ years & 353 & 37.9 \\
\hline 20 years - & 393 & 42.2 \\
\hline 22 years or more & 185 & 19.9 \\
\hline Mean \pm SD (Range) & \multicolumn{2}{|c|}{$20.14 \pm 1.40(18.0-24.0)$} \\
\hline \multicolumn{3}{|l|}{ Sex: } \\
\hline Male & 241 & 25.9 \\
\hline Female & 690 & 74.1 \\
\hline \multicolumn{3}{|l|}{ Father education } \\
\hline Illiterate & 130 & 14.0 \\
\hline Read \& write & 83 & 8.9 \\
\hline Basic education & 186 & 20.0 \\
\hline Secondary & 271 & 29.1 \\
\hline University & 207 & 22.2 \\
\hline $\begin{array}{l}\text { Postgraduate } \\
\end{array}$ & 54 & 5.8 \\
\hline \multicolumn{3}{|l|}{ Mother education } \\
\hline Illiterate & 290 & 31.1 \\
\hline Read \& write & 96 & 10.3 \\
\hline Basic education & 166 & 17.9 \\
\hline Secondary & 209 & 22.4 \\
\hline University & 140 & 15.1 \\
\hline Postgraduate & 30 & 3.2 \\
\hline \multicolumn{3}{|l|}{ Father occupation } \\
\hline Farmer & 211 & 22.7 \\
\hline Employee & 528 & 56.7 \\
\hline Skilled worker & 19 & 2.1 \\
\hline Un skilled worker & 73 & 7.8 \\
\hline Free business & 100 & 10.7 \\
\hline \multicolumn{3}{|l|}{ Mother occupation } \\
\hline Housewife & 187 & 20.1 \\
\hline Employee & 744 & 79.9 \\
\hline \multicolumn{3}{|l|}{ Residence } \\
\hline Rural & 584 & 62.7 \\
\hline Urban & 347 & 37.3 \\
\hline
\end{tabular}

Table (2): Distribution of the studied students regarding to their past history of food allergy at Assiut University, $(\mathrm{N}=931)$.

\begin{tabular}{|l|c|c|}
\hline \multicolumn{1}{|c|}{ Past history of food allergy } & No. $(\mathbf{n}=\mathbf{9 3 1})$ & \% \\
\hline Allergy to any particular type of food & $\mathbf{2}$ \\
\hline Yes & $\mathbf{2 0 8}$ & 22.3 \\
\hline No & 723 & 77.7 \\
\hline Type of food: $\left(^{\wedge}\right)(208)$ & 62 & 29.8 \\
\hline Sea food (Fish, Shellfish) & 56 & 26.9 \\
\hline Fruits (strawberry) & 43 & 20.6 \\
\hline Diary product (cheese, Milk) & 35 & 16.8 \\
\hline Vegetables & 26 & 12.5 \\
\hline Poultry and it's product (chicken, egg) & 14 & 6.7 \\
\hline Chocolate & 14 & 6.7 \\
\hline Species & 12 & 5.8 \\
\hline Legumes (peanuts, tree nuts, soy) & 6 & 2.9 \\
\hline Meat & \multicolumn{2}{|l|}{} \\
\hline
\end{tabular}

$(\wedge)$ More than one answer was select 
Table (3): Distribution of the studied students regarding to their family history of disease at Assiut University, $(\mathrm{N}=931)$.

\begin{tabular}{|l|c|c|}
\hline \multicolumn{1}{|c|}{ Items } & No. $(\mathbf{n}=\mathbf{9 3 1})$ & \% \\
\hline Family history of allergy: & \multicolumn{2}{|c|}{} \\
\hline Yes & $\mathbf{2 7 8}$ & 29.9 \\
\hline No & 653 & 70.1 \\
\hline No. of exposed family members:(278) & 200 & 71.9 \\
\hline One & 58 & 20.9 \\
\hline Two & 12 & 4.3 \\
\hline Three & 8 & 2.9 \\
\hline More than three & \multicolumn{2}{|c|}{} \\
\hline Relation of relatives:(^) (278) & 210 & 75.5 \\
\hline Brother and Sister & 119 & 42.8 \\
\hline Parents & 42 & 15.2 \\
\hline Uncle and Aunt ( for mother, father) & 16 & 5.8 \\
\hline Grandfather and Grandmother & \multicolumn{2}{|c|}{} \\
\hline
\end{tabular}

$\left(^{\wedge}\right)$ More than one answer was select

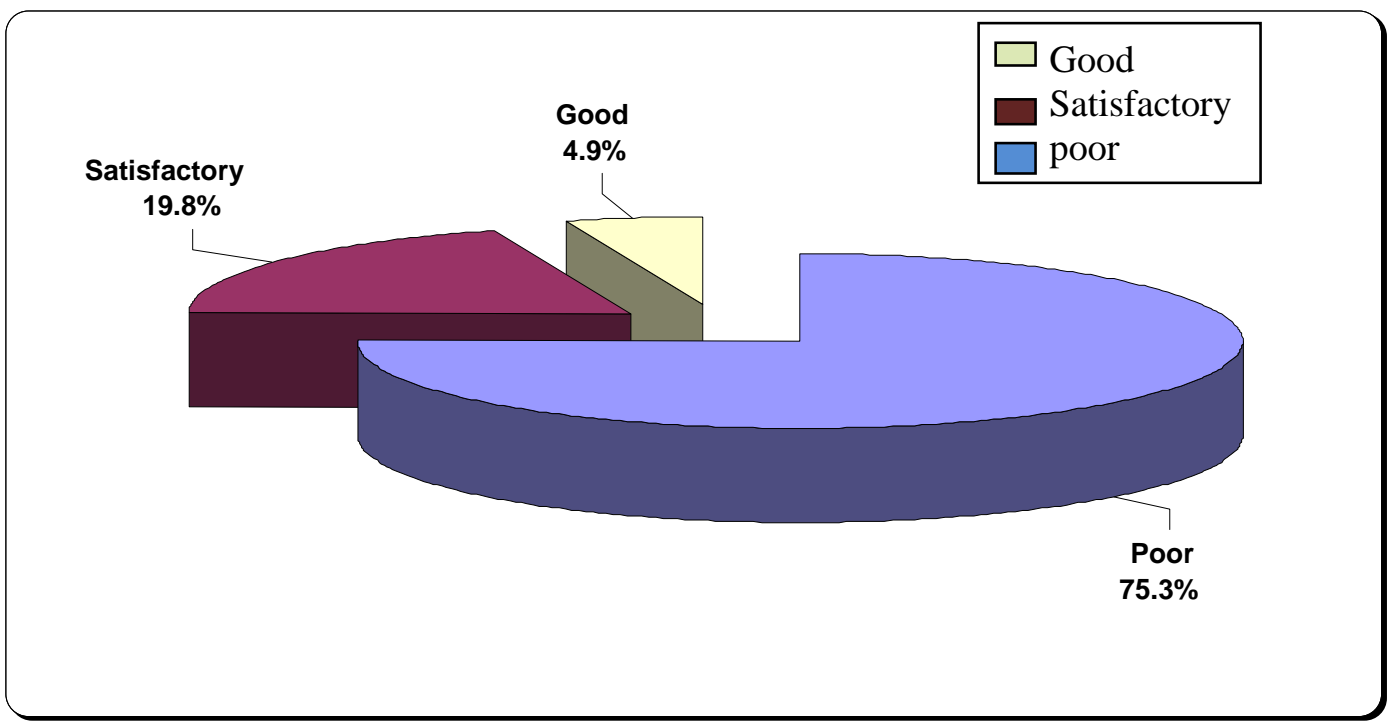

Figure (1): Distribution of the studied students regarding their knowledge's score about food allergy at Assiut University.

Table (4): Relation between the studied student's knowledge about food allergy and some of sociodemographic data at Assiut University, (N=931).

\begin{tabular}{|c|c|c|c|c|c|c|c|}
\hline \multirow{3}{*}{ Items } & \multicolumn{6}{|c|}{ Level of knowledge } & \multirow{3}{*}{ P-value } \\
\hline & \multicolumn{2}{|c|}{$\begin{array}{c}\text { Poor }(75.3 \%) \\
(n=701)\end{array}$} & \multicolumn{2}{|c|}{$\begin{array}{c}\text { Satisfactory }(19.8 \%) \\
(n=184)\end{array}$} & \multicolumn{2}{|c|}{$\begin{array}{c}\operatorname{Good}(4.9 \%) \\
(n=46)\end{array}$} & \\
\hline & No. & $\%$ & No. & $\%$ & No. & $\%$ & \\
\hline \multicolumn{7}{|l|}{ Age } & \multirow{4}{*}{0.079} \\
\hline$<20$ years & 257 & 36.7 & 74 & 40.2 & 22 & 47.8 & \\
\hline $20-21$ years & 296 & 42.2 & 75 & 40.8 & 22 & 47.8 & \\
\hline 22 years or more & 148 & 21.1 & 35 & 19.0 & 2 & 4.3 & \\
\hline \multicolumn{7}{|l|}{ Sex } & \multirow{3}{*}{$0.006^{*}$} \\
\hline Male & 171 & 24.4 & 49 & 26.6 & 21 & 45.7 & \\
\hline Female & 530 & 75.6 & 135 & 73.4 & 25 & 54.3 & \\
\hline
\end{tabular}




\begin{tabular}{|c|c|c|c|c|c|c|c|}
\hline \multirow{3}{*}{ Items } & \multicolumn{6}{|c|}{ Level of knowledge } & \multirow{3}{*}{ P-value } \\
\hline & \multicolumn{2}{|c|}{$\begin{array}{c}\text { Poor }(\mathbf{7 5 . 3 \%}) \\
\quad(n=701)\end{array}$} & \multicolumn{2}{|c|}{$\begin{array}{c}\text { Satisfactory }(19.8 \%) \\
(n=184)\end{array}$} & \multicolumn{2}{|c|}{$\begin{array}{c}\operatorname{Good}(4.9 \%) \\
(n=46)\end{array}$} & \\
\hline & No. & $\%$ & No. & $\%$ & No. & $\%$ & \\
\hline \multicolumn{7}{|l|}{ Father education } & \multirow{7}{*}{$0.045^{*}$} \\
\hline Illiterate & 100 & 14.3 & 27 & 14.7 & 3 & 6.5 & \\
\hline Read \& write & 62 & 8.8 & 20 & 10.9 & 1 & 2.2 & \\
\hline Basic education & 142 & 20.3 & 39 & 21.2 & 5 & 10.9 & \\
\hline Secondary & 207 & 29.5 & 50 & 27.2 & 14 & 30.4 & \\
\hline University & 151 & 21.5 & 38 & 20.6 & 18 & 39.1 & \\
\hline Postgraduate & 39 & 5.6 & 10 & 5.4 & 5 & 10.9 & \\
\hline \multicolumn{7}{|l|}{ Mother education } & \multirow{7}{*}{$0.000^{*}$} \\
\hline Illiterate & 225 & 32.1 & 58 & 31.5 & 7 & 15.2 & \\
\hline Read \& write & 72 & 10.3 & 18 & 9.8 & 6 & 13.0 & \\
\hline Basic education & 127 & 18.1 & 33 & 17.9 & 6 & 13.0 & \\
\hline Secondary & 162 & 23.1 & 43 & 23.4 & 4 & 8.7 & \\
\hline University & 96 & 13.7 & 25 & 13.6 & 19 & 41.3 & \\
\hline Postgraduate & 19 & 2.7 & 7 & 3.8 & 4 & 8.7 & \\
\hline \multicolumn{7}{|l|}{ Residence } & \multirow{3}{*}{0.158} \\
\hline Rural & 441 & 62.9 & 120 & 65.2 & 23 & 50.0 & \\
\hline Urban & 260 & 37.1 & 64 & 34.8 & 23 & 50.0 & \\
\hline
\end{tabular}

Chi-square test $*$ Statistical significant difference $(P<0.05)$

Table (5): Distribution of the studied student's attitudes towards food allergy at Assiut University, (N=931).

\begin{tabular}{|c|c|c|c|c|c|c|c|c|c|c|}
\hline \multirow[t]{2}{*}{ Items } & \multicolumn{2}{|c|}{$\begin{array}{l}\text { Strongly } \\
\text { Disagree }\end{array}$} & \multicolumn{2}{|c|}{ Disagree } & \multicolumn{2}{|c|}{ Neutral } & \multicolumn{2}{|c|}{ Agree } & \multicolumn{2}{|c|}{$\begin{array}{l}\text { Strongly } \\
\text { Agree }\end{array}$} \\
\hline & No. & $\%$ & No. & $\%$ & No. & $\%$ & No. & $\%$ & No. & $\%$ \\
\hline $\begin{array}{l}\text { It's important for me to know accurate } \\
\text { information about food ingredients and } \\
\text { provide this information to people who suffer } \\
\text { from a food allergy }\end{array}$ & 59 & 6.3 & 31 & 3.3 & 85 & 9.1 & 430 & 46.2 & 326 & 35.0 \\
\hline $\begin{array}{l}\text { Believes that the prevention of food allergy is } \\
\text { an important part of your job responsibilities }\end{array}$ & 22 & 2.4 & 137 & 14.7 & 295 & 31.7 & 375 & 40.3 & 102 & 11.0 \\
\hline Allergic food can avoid occurrence & 34 & 3.7 & 39 & 4.2 & 192 & 20.6 & 447 & 48.0 & 219 & 23.5 \\
\hline $\begin{array}{l}\text { Know information about food allergy reduces } \\
\text { the likelihood of complications }\end{array}$ & 18 & 1.9 & 61 & 6.6 & 132 & 14.2 & 404 & 43.4 & 316 & 33.9 \\
\hline $\begin{array}{l}\text { Believes that small amounts of allergenic } \\
\text { foods is not sufficient to cause a food allergy }\end{array}$ & 122 & 13.1 & 286 & 30.7 & 290 & 31.1 & 176 & 18.9 & 57 & 6.1 \\
\hline Should educate mothers about food allergy & 20 & 2.1 & 18 & 1.9 & 97 & 10.4 & 311 & 33.4 & 485 & 52.1 \\
\hline $\begin{array}{l}\text { I think it's important to attend educational } \\
\text { sessions about food allergy }\end{array}$ & 18 & 1.9 & 43 & 4.6 & 190 & 20.4 & 358 & 38.5 & 322 & 34.6 \\
\hline $\begin{array}{l}\text { Are you willing to change my food handling } \\
\text { behaviors related to handling food allergens }\end{array}$ & 49 & 5.3 & 48 & 5.2 & 167 & 17.9 & 409 & 43.9 & 258 & 27.7 \\
\hline $\begin{array}{l}\text { Believes that the individuals involved in food } \\
\text { preparation more knowledgeable about food } \\
\text { allergy }\end{array}$ & 62 & 6.7 & 206 & 22.1 & 265 & 28.5 & 274 & 29.4 & 124 & 13.3 \\
\hline $\begin{array}{l}\text { Believes that knowledge about food allergy } \\
\text { makes you more careful in dealing with food }\end{array}$ & 21 & 2.3 & 33 & 3.5 & 148 & 15.9 & 422 & 45.3 & 307 & 33.0 \\
\hline $\begin{array}{l}\text { Believes that understanding the basics about } \\
\text { food allergy be useful for you }\end{array}$ & 23 & 2.5 & 42 & 4.5 & 105 & 11.3 & 437 & 46.9 & 324 & 34.8 \\
\hline $\begin{array}{l}\text { It is important for me personally to learn } \\
\text { more about food allergy }\end{array}$ & 19 & 2.0 & 41 & 4.4 & 143 & 15.4 & 401 & 43.1 & 327 & 35.1 \\
\hline
\end{tabular}




\begin{tabular}{|l|c|c|c|c|c|c|c|c|c|c|}
\hline \multicolumn{2}{|c|}{ Items } & \multicolumn{2}{|c|}{$\begin{array}{l}\text { Strongly } \\
\text { Disagree }\end{array}$} & \multicolumn{2}{c|}{ Disagree } & \multicolumn{2}{|c|}{ Neutral } & \multicolumn{2}{|c|}{ Agree } & \multicolumn{2}{c|}{$\begin{array}{c}\text { Strongly } \\
\text { Agree }\end{array}$} \\
\cline { 2 - 13 } & No. & $\%$ & No. & $\%$ & No. & $\%$ & No. & $\%$ & No. & $\%$ \\
\hline $\begin{array}{l}\text { Think you are able to deal effectively in the } \\
\text { event of a state of emergency especially } \\
\text { sensitive food }\end{array}$ & 142 & 15.3 & 193 & 20.7 & 272 & 29.2 & 229 & 24.6 & 95 & 10.2 \\
\hline $\begin{array}{l}\text { Believes that it must be all the people } \\
\text { familiar with accurate information about food } \\
\text { allergy }\end{array}$ & 33 & 3.5 & 46 & 4.9 & 131 & 14.1 & 365 & 39.2 & 356 & 38.2 \\
\hline
\end{tabular}

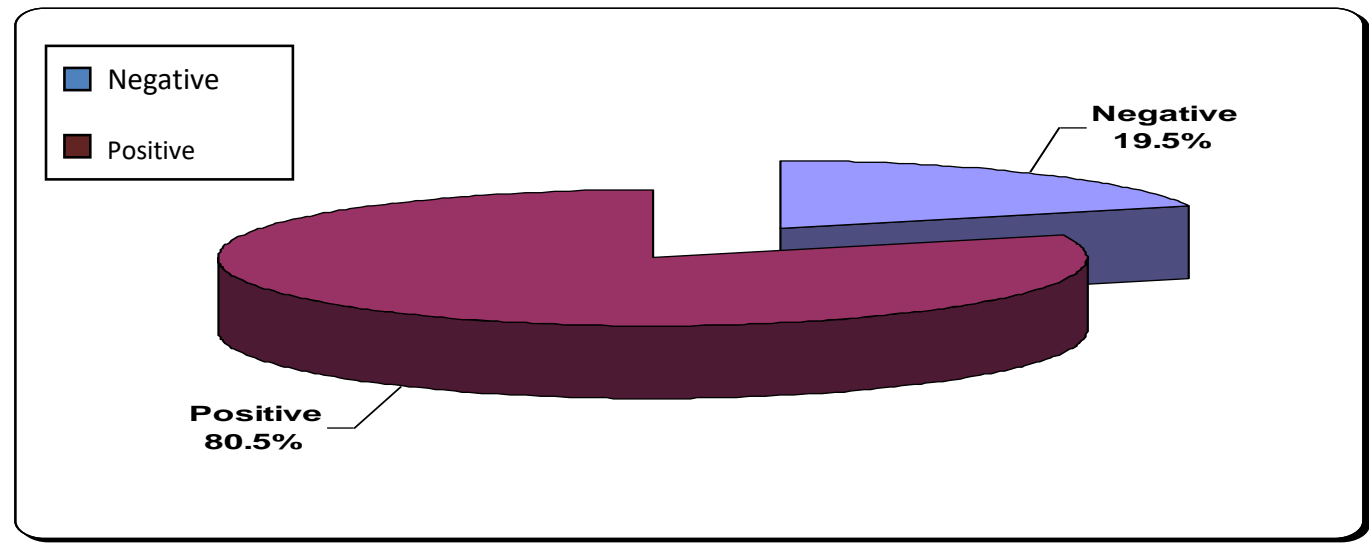

Figure (2): Distribution of studied student's attitude about food allergy at Assiut University,2016.

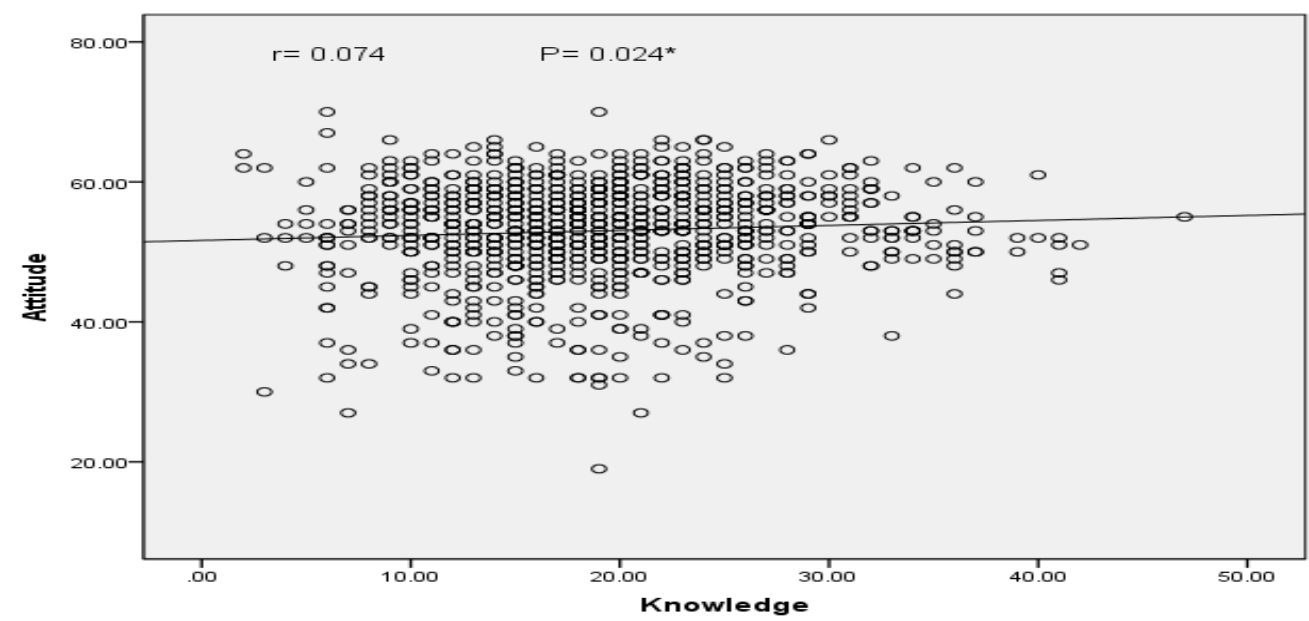

Spearman correlation

Figure (3): Correlation between knowledge and attitude of studied students about food allergy

Table (1): Shows $37.9 \%$ of students' aged $<20$ years and $42.2 \%$ of them their age were 20 years old. The mean age \pm SD was $20.14 \pm 1.40$. As regard to gender, $25,9 \%$ of the students were males and $74.1 \%$ were females.

According to their parent's education, it was found that $22.2 \%$ of students' father had university education, while $15.1 \%$ of students' mothers had university education. Concerning occupation of their parents, it was estimated that $56.7 \%$ of students' father were employee, while $79.9 \%$ of students' mother were employee. Regarding to residence, $62.7 \%$ of students live in rural area and $37.3 \%$ of them live in urban area.

Table (2): Illustrates that $22.3 \%$ of the studied students had allergy to any particular type of food, 
while $77.7 \%$ of them hadn't allergy to any food. Regarding to type of food which cause allergy, it was revealed that $(29.8 \%, 26.9 \%, 20.6 \%, 16.8 \%$, $12.5 \%, 6.7 \%, 6.7 \%, 5.8 \%$ and $2.9 \%$ ) of studied students had allergy to sea foods, fruits, dairy products, vegetables, poultry and its' product, chocolate, species, legumes and meat respectively.

Table (3): Reveals that $70.1 \%$ of students haven't family history of food allergy, while $29.9 \%$ of them have family history of food allergy. Regarding to relation of relative, $75.5 \%$ of studied students had positive family history for both brother and sister.

Figure (1): Shows that $75.3 \%$ of studied students had poor score of knowledge and $19.8 \%$ of them had satisfactory score of knowledge, while only $4.9 \%$ of them had good score of knowledge.

Table (4): Show the relation between student's knowledge about food allergy and their sociodemographic data, it was observed that $47.8 \%$ of studied students $<20$ years were good knowledge, while $36.7 \%$ of them were poor knowledge. As regarding to sex, it revealed that $45.7 \%$ of male students were good knowledge, while $54.3 \%$ of female students were good knowledge with statistically significance was found $\mathrm{P}=0.006^{*}$.

According to fathers' education, it revealed that $39.1 \%$ of them had university fathers were good knowledge, while only $6.5 \%$ of them had illiterate fathers were good knowledge with statistically significance was found $\mathrm{P}=0.045$. Regarding mothers' education, it found that $41.3 \%$ had university mothers were good knowledge, while only $15.2 \%$ of them had illiterate mothers were good knowledge with statistically significance was found $\mathrm{P}=0.000$.

Regarding to residence, $50.0 \%$ of the urban studied students were good knowledge, while $62.9 \%$ of rural studied students were poor knowledge.

Table (5): Indicates that $52.1 \%$ of the studied students strongly agreed that should educate mothers about food allergy, while only $2.1 \%$ of them strongly disagreed about it and $30.7 \%$ of them disagreed that small amount of allergenic foods is not sufficient to cause food allergy, while only $18.9 \%$ of them agreed about it and $40.3 \%$ of the studied students agreed that prevention of food allergy is important part of their job responsibilities, while only $14.7 \%$ of them disagreed about it.

Figure(2): Illustrates that $80.5 \%$ of the studied students had positive attitudes toward food allergy, while $19.5 \%$ of them had negative attitudes .

Figure (3): Illustrates a positive Correlation between score of knowledge and attitudes of studied students about food allergy

\section{Discussion}

College represents a unique time in young adults life. For most individuals, this is the first experience supervision, and responsibility is shifted to these individuals in all aspects of life. Such responsibilities include making sure Self-Injection Epinephrine (SIE) prescriptions are filled and up-to-date, carrying the device at all times, familiarizing persons preparing their food with their specific needs, and remembering what is safe to eat (Mathew et al., 2009).

Concerning the age groups of the studied students, the results of the present study was found that the age of student range from 20- 21 years ,these results agree with Alexandra et al., (2016) who conducted a study on "You're Totally on Your Own": Experiences of Food Allergy on a Canadian University Campus and reported that the age of students ranged from 18-21. Also; in the same line with Stephanie et al., (2014) who exploring perceptions and experiences of food allergy among New Canadians from Asia and reported the range of students age 18-21 years.

While this finding disagreed with Keiichiro \& Akemi, (2012) Who carried out Study about food allergy among university students in Japan and found that the student age range from 18-41 years. Also; These results disagree with Ji Hee Choi \& lakshman, (2013) who conducted study to assess food allergy knowledge, attitude, practices and training of food service workers at university food service operation in the Midwestern United States and reported that students age range from 18-49 years old.

According to the student sex, the result of the present study revealed that about three quarter of the studied students were females while about one quarter of them were males these results agree with Stephanie et al., (2014) who reported that more than three quarter of the studied students were female and $22 \%$ of them were male.

Also; disagreement with Alexandra et al., (2016) who reported slightly less than two third of the studied students were females while two fifth of them were males. As well as Ji Hee Choi \& lakshman, (2013) who reported that less than two third of students were females and slightly more than one third of them were males. This may be attribute to female students more committed to attend the lectures than male students and percentage of male students in university less than female students.

According to present history of allergy to any particular food ,the present study revealed that $22.3 \%$ had food allergy and more than one quarter of the studied students who had food allergy complained from sea food that is the most common food that can 
cause food allergy to people, this result agree with Alexandra et al., (2016) who reported that one quarter of studied students had allergy to sea food. Also agree with Mathew et al., (2009) who study of food allergy and food allergy attitude among college students and found that about slightly more than one fifth of them had allergy to seafood.

While results disagreement with Redhwan et al., (2011) who conducted a study related to Perceptions about food allergy among medical science students in Shah Alam, Selangor, Malaysia university and found that slightly more than one third of participants were had allergy to seafood. Also this finding disagreed with Keiichiro \& Akemi (2012) who show that allergy to sea food constituted $10.6 \%$ of the studied students.

Concerning the family history of food allergy, the current study indicated that slightly more than two third of studied students had not family history of food allergy and more than one quarter of them had family history to food allergy, this finding was disagreed with Redhwan et al., (2011) who reported that the majority of students mentioned that food allergies do run in families, $13.3 \%$ of the students mentioned that food allergy do not run in families.

According to the total score of knowledge for students about food allergy, this study revealed that more than three quarter of them were poor and $4.9 \%$ of the student had good knowledge that may be due to the educational program of studied students which doesn't contain course about nutrition in their curriculum.

Concerning to the relation between studied student's level of knowledge about food allergy and their sex, the current study represented that more than half of females' studied students had good knowledge, while less than half of males' studied students had good knowledge with statistically significance was found $\mathrm{P}=0.006$. This may be due to female students more interest and participate in food preparation and like to identify any information about food and cooking than male students.

According to relation between studied student's level of knowledge about food allergy and mother's education, the current study revealed that half of studied students had university and postgraduate mothers were good knowledge, while only $15.2 \%$ of them had illiterate mothers were good knowledge with statistically significance was found $\mathrm{P}=0.000$. This may be attribute to university and postgraduate mothers were more knowledgeable about nature of disease and prevention and told their sons any information which benefit them than illiterate mothers.

As regard to the students' attitudes toward "small amounts of allergenic foods which is not sufficient to cause a food allergy", the present study founded that only $13.1 \%$ of students strongly disagreement on this statement, this may be attribute to studied students which doesn't know nature of food allergy disease due to lack of study course about nutrition in their curriculum and Muraro et al., (2014) reported that small amounts about $0.2 \mathrm{mg}$ of foods very sufficient to appears signs and symptoms of food allergy disease. This results disagree with Ji Hee Choi \& lakshman, (2013) who reported that more than half of the studied students strongly disagree on small amounts of allergenic foods is not sufficient to cause a food allergy.

Regarding to the students' attitudes toward "mothers should be educated about food allergy", more than half of students strongly agreed on this statement, this is may be attribute to believe of studied students when mothers become more knowledgeable about nature of food allergy disease she will avoid the occurrence of it and follow tips for preparing, cooking and eating food at home to decrease fear, anxiety and stress to their children.

Concerning to the students' attitudes toward "think to deal efficiently in the event of state of emergency especially to sensitive food", it was observed that less than one quarter of studied students agreed on this statement. Agreement of small number of students may attributable to insufficient amount of knowledge about food allergy and insufficient training how to deal in emergency case of food allergy while these results disagree with Ji Hee Choi \& lakshman (2013) who reported that more than one third of studied students agreed on think to deal efficiently in the event of state of emergency especially to the sensitive food

As regard to student's attitude about food allergy, the present study revealed that the majority of studied student had positive attitude toward food allergy while about one fifth of studied student had negative attitude it is due to Egyptian culture like to help others and need to identify all information about nature of disease. There was a positive Correlation between score of knowledge and attitude of studied students about food allergy

\section{Conclusion}

Based on the results of the present study and reassessed questions, it can be concluded that

More than three quarters of studied students had poor score of knowledge about food allergy while small number of them had good score of knowledge about food allergy while the majority of studied students had positive attitude toward food allergy. There is statistically significant regarding total score of knowledge, sex and mother education. There is 
positive correlation between total score of knowledge and attitude of studied students.

\section{Recommendations}

Based on the results of the present study, the following recommendations are suggested

- Develop plan, and implement health education programs for university students about food allergy and it included the following: importance of avoidance eating of high allergic foods as the protein content in Lactating mothers because they may pass in the breast milk and cause lifelong allergy for her baby.

- Increase the amount of periodicals and books in the different faculties libraries regarding food allergy.

- Increase awareness of students about importance of exclusive breast feeding in infants for the first 46 months.

- Guideline book should be prepared and distributed to all maternal and child health $(\mathrm{MCH})$ center for instructions about food allergy.

\section{References}

1. Abd El Rhman, M., (2014): Knowledge and Opinion of Assiut University Students toward organ donation and transplantation submitted for partial fulfiiment of the master degree in community health nursing.

2. Alexandra S., Olarnyk1, Susan J., \& Elliott, (2016): You're Totally on Your Own": Experiences of Food Allergy on a Canadian University Campus, Universal Journal of Public Health ,volum 4,(1),pp31-37.

3. Boye, J., (2012): Food allergies in developing and emerging economies, need for comprehensive data on prevalence rates. Clinical and Translational Allergy, vol 2, (1), pp 25.

4. Burks A., Tang M., Sicherer S., Muraro A., Eigenmann P., \& Ebisawa M., (2012): ICON: food allergy. J Allergy Clin Immunol; volum129, pp906-20.

5. Chafen J., Newberry S., Riedl M., Bravata D., Maglione M., \& Suttorp M., (2010): Diagnosing and managing common food allergies: asystematic review. JAMA.; volum303(18),pp1848-56.

6. Dillman D., Smyth J., \& Christian L., (2007): Internet, mail, and mixed-mode surveys: The tailored design method. Hoboken, NJ: John Willy \& Son, Inc ,pp 45

7. Food Allergy \& Anaphylaxis Network (FAAN), (2011): Food allergy facts and statistics. http://www.foodallergy.org/ downloads/ Food Allergy Factsand Statistics
8. Greenhawt M., Singer A., \& Baptist A., (2009): Food allergy and food allergy attitudes among college students. Journal of Allergy and Clinical Immunology, volum124, pp 323-327.

9. Harold S., Nelson H., Hipkins S., \& Rutkowski S., (2007) : What are food allergies? Food allergy summary, Asthma and Allergy Foundation of America, Egyptian journal of internal medicine, vol(25),pp1-9.

10. Hossny E., Gad G., Shehab A., \& El-Haddad A., (2011): Peanut sensitization in a group of allergic Egyptian children. Allergy Asthma Clin Immunol; vol $25,(1)$, pp 7:11.

11. Ji Hee Choi \& lakshman R., (2013): food allergy knowledge, attitude, practices and training of food service workers at university food service operation in the Midwestern united states, 474-481,food control journal home page:www. elsevier.com locatelfood cont.

12. Keiichiro Yoneyama \& Akemi, (2012): Study of food allergy among university students in Japan, Health Service Center, Showa University, Tokyo, Allergology International, volum 51,pp 205-208.

13. Malaysia Ministry of Health (MOH), (2013): Malaysian Dietary Guidelines for Children and Adolescents , pp 1-74.

14. Mathew J., Greenhawt M., \& Andrew M., (2009): Food allergy and food allergy attitude among college students, J allergy clinic immunol, volum 124,number 2 ,Pp 323-327.

15. Muraro A., Werfel T., HoffmannSommergruber K., Roberts G., Beyer K., Bindslev-Jensen C., Cardona V., Dubois A., duToit G., Eigenmann P., Fernandez Rivas M., Halken S, Hickstein L., Host A., Knol E., Lack G., Marchisotto M., Niggemann B., Nwaru B., Papadopoulos N, Poulsen L, Santos A., Skypala I., Schoepfer A., Van Ree R., Venter C., Worm M., Vlieg-Boerstra B., Panesar S., de Silva D., Soares-Weiser K., Sheikh A., Ballmer-Weber B., Nilsson C., de Jong N., Akdis C., \& the EAACI Food Allergy Anaphylaxis Guidelines Group, (2014): EAACI food allergy and anaphylaxis guidelines: diagnosis and management of food allergy. Allergy, volum(69), p.p 1008-1025.

16. National Institute of Allergy \& Infectious Diseases. (2010): Is it Food Allergy or Food Intolerance? National Institutes of Health.http://www.niaid.nih.gov/topics/foodaller gy/understanding/pages/foodintolerance.aspx

17. Norrina B., (2015): Gauging Food Allergy Knowledge among Hospitality Students , Journal of Management Research ISSN, Vol. 7,1941- 
899X 2015, No. 2 ,www.macrothink.org/jmr 252.

18. Pawankar, R., Canonica, W., Holgate, S., \& Lockey, R., (2011): WAO White Book on Allergy, $19^{\text {th }}$ edition, chapter 45 ,Adverse reactions to foods, Executive Summary, p.36.

19. Redhwan, A., Low, W., Mustafa, F., Robert, C., \& Ali, A., (2011): Perceptions about food allergy among medical science students in a university in Shah Alam, Selangor, Malaysia, International Food Research Journal ,volum18,pp 451-458.

20. Sicherer S., \& Leung D., (2011): Advances in allergic skin disease, anaphylaxis, and hypersensitivity reactions to foods, drugs, and insects in 2010. J Allergy Clin Immunol;volum127,pp326-35.

21. Smeltzer S., Bare B., Hinkle J., \& Cheever K., (2008): Brunner and Suddarth Text book of medical - surgical nursing, Eleventh edition, Chapter 53, Assessment and management of patient with allergic disorders, lippincott wiliams and wilkins, awolters kluwer business, vol(2), pp.1879-1880.

22. Stephanie K., Susan J., Elliott, \& Ann E., Clarke, (2014): Exploring Perceptions and Experiences of Food Allergy among New Canadians from Asia, Journal of Allergy, Article ID $964504, \quad 7$ pages http://dx.doi.org/10.1155/2014/964504 